\title{
Identifikasi dan Analisis Filogenetik Portunus trituberculatus Dari Perairan Cirebon Menggunakan Barkode Gen COI Mitokondrial
}

\author{
Subagiyo ${ }^{1 *}$, Ch. Retna Handayani2, Rahayu2 dan Triandala Mada Sibero' \\ 'Departemen Ilmu Kelautan, Fakultas Perikanan dan IlmuKelautan, Universitas Diponegoro \\ Jl. Prof. Soedarto, SH. Tembalang, Semarang 50275 Indonesia \\ 2Balai Besar Perikanan Budidaya Air Payau \\ Jl. Cik Lanag Bulu Jepara 59418 Indonesia \\ Email: subagiyo.kelautan13@gmail.com
}

\begin{abstract}
Phylogenetic Identification and Analysis Portunus trituberculatus from Cirebon Coast Using the COI Barcode Mitochondrial
\end{abstract}

Portunus trituberculatus spesimen from Cirebon coast were successfully identified using mitochondrial DNA cytochrome c oxydase subunit I (COI) genes. Analysis of haplotype distribution of $\mathrm{P}$. trituberculatus along with the same species from China, Korea, India and the Philippines obtained from NCBI gene banks resulted 17 haplotypes from 25 specimens. Haploid diversity was $0.943 \pm 0.031$ and nucleotide diversity was $0.04821 \pm 0.0139$. The Cirebon specimen is in separated haplotipe from the others. The results of phylogenetic analysis showed that the 25 specimens were clustered into 3 clusters in 2 different lineages with percentages genetic distance were $12.76 \%$, $14.24 \%$ and $14.33 \%$ respectively. The genetic distance within each cluster ranges from $0-2.92 \%$. The Cirebon crab specimen is in the same cluster as the Philippine specimen with $1 \%$ genetic distance.

Keywords : crab; Portunus trituberculatus; barcoding; gen COI

\begin{abstract}
Abstrak
Spesimen rajungan Portunus trituberculatus dari perairan Cirebon berhasil diidentifikasi menggunakan gen mitochondrial DNA cytochrome c oxidase subunit I (COI). Analisis distribusi haplotipe dengan data $P$ trituberculatus yang berasal dari China, Korea, India dan Filipina yang diperoleh dari data genebank NCBI didapatkan 17 haplotipe dari 25 spesimen, dengan keragaman haploid 0,943 \pm 0.031 dan keragaman nukleotida 0,04821+0.0139. Spesimen Cirebon merupakan haplotipe yang terpisah dari yang lainnya. Hasil kajian filogenetik menunjukkan 25 spesimen mengelompok ke dalam 3 kluster dari 2 garis keturunan yang berbeda dengan jarak genetik berturut turut $12,76 \%, 14,24 \%$ dan $14,33 \%$. Jarak genetik di dalam masing-masing kluster berkisar antara $0-2,92 \%$. Spesimen rajungan Cirebon berada pada garis keturunan dan kluster yang sama dengan spesimen Filipina dengan jarak genetik $1 \%$.
\end{abstract}

Kata kunci : rajungan; Portunus trituberculatus; barcoding; gen COI

\section{PENDAHULUAN}

Portunus. trituberculatus dikenal dengan nama lain gazami crab, Japanese blue crab atau horse crab. Spesies ini memiliki distribusi geografis di Samudera Hindia dan Samudera Pasifik Barat: Asia Tenggara dan Timur (dari Jepang, Korea, Cina dan Formosa dan Teluk Bengala), ke Barat, Utara dan Timur
Australia (FAO, 2018). Menurut Liu et al. (2013) $P$. trityberculatus merupakan hasil perikanan tangkap terbesar di dunia (menempati sekitar seperempat tangkapan komersial di seluruh dunia). Sebagian besar dari total tangkapan kepiting ini (95\%) terjadi di Cina di tiga daerah penangkapan utama: Laut Cina Timur, Laut Kuning, dan Laut Bohai. Di Indonesia $P$. trituberculatus merupakan 
spesies yang jarang ditemukan (Irawan dan Soegianto, 2006).

$P$. trituberculatus secara umum memiliki penampilan yang mirip dengan Portunus pelagicus. $P$. trituberculatus dibedakan dari $P$. pelagicus karena memiliki 3 gigi frontal ( 4 di $P$. pelagicus) dan memiliki 4 duri di merus cheliped (3 di P. pelagicus) (FAO (2018), sehingga dapat dengan mudah diidentifikasi secara fenotipik. Selanjutnya untuk mengetahui adanya variasi atau keragaman intraspesik diperlukan pendekatan molelular diantaranya adalah menggunakan urutan gen mtDNA (Habib, et al., 2011) yang dikenal dengan nama DNA barcoding (Raupach \& Radulovici. 2015). Data barcoding $P$ trituberculatus di Indonesia masih belum ada. Oleh karena itu spesimen $P$ trituberculatus yang tertangkap di perairan Cirebon pada tahun 2016 ini akan dilakukan analisis barcoding dan membandingkannya dengan data spesies yang sama yang ada di database BOLD (The Barcode of Life Data System) dan gene bank NCBI (The National Center for Biotechnology Information).

DNA barcoding merupakan tool yang kuat untuk mengidentifikasi dan mengkonfirmasikan spesies (Shen et al., 2013). Marka gen DNA mitokondria yang mengkodekan gen sitokrom oksidase (COI) umum digunakan untuk barkoding. Variasi intraspesifik biasanya kurang dari 2,0\% dan dalam banyak kasus kurang dari 1,0\% (Shen et al., 2013). Penggunaan gen COI sebagai marka untuk barcoding dan identifikasi jenisjenis kepiting telah memberikan banyak hasil seperti Portunus sanguinolentus, Charybdis natator, P. pelagicus, P.trituberculatus dan Travancoriana napaea (Umamaheswari et al, 2016), fiddler crabs Uca annulipes dan U. perplexa (Abbas et al., 2016). Selain itu DNA barcoding juga digunakan untuk studi keragaman genetic Portunus pelagicus (Klinbunga, et al., 2010; Sienes et al., 2014; Ren et al., 2017), P. trituberculatus (Guo et al., 2012), Portunus sanguinolentus (Naz et al., 2016; Ren et al., 2017). Pada penelitian ini DNA barcode juga digunakan untuk mengevaluasi perbedaan intraspesifik dari berbagai lokasi tangkap di dunia yang datanya diperoleh dari gene bank (NCBI) yang selanjutnya digunakan untuk mengetahui ada tidaknya perbedaan jalur keturunannya. Penelitian mengenai filogenetik rajungan menggunakan gene penanda $\mathrm{COI}$ juga telah berhasil dilakukan (Mantelatto et al., 2007; Fujaya, et al., 2016).

\section{MATERI DAN METODE}

Spesimen rajungan diperoleh dari tangkapan nelayan Cirebon yang melakukan kegiatan penangkapan di perairan Cirebon (one day fishing). Satu spesimen yang diperoleh langsung diidentifikasi secara fenotipik dan diambil bagian capit kemudian diawetkan menggunakan ethanol $96 \%$ sampai dilakukan analisis molekular.

\section{Ekstraksi DNA}

DNA genom rajungan diekstraksi dengan metode menggunakan Chelex 5\% menurut Aranishi \& Okimoto (2006) yang dimodifikasi. Sampel capit depan rajungan diambil bagian ototnya menggunakan pinset steril dan dihancurkan dengan mortar dalam lumpang porselin. Homegenat yang diperoleh ditambahkan buffer TE (1 mM EDTA, $10 \mathrm{mM}$ Tris: $\mathrm{pH}$ 8.0), dihomogenkan dan dibiarkan selama 15 menit pada suhu ruangan. Suspensi homogenate ini disnetrifugasi pada kecepatan $10.000 \mathrm{rpm}$ untuk mendapatkan massa sel. Massa sel yang diperoleh kemudian ditambahkan Chelex $5 \%$ dan proteinase $\mathrm{K}$ selanjutnya divortex. Suspensi sel ini diinkubasi pada suhu $56{ }^{\circ} \mathrm{C}$ selama 15-30 menit, Selanjutnya dimasukkan ke dalam penangas air yang mendidih selama 8 menit. DNA genom diperoleh dengan cara sentrifugasi pada kecepatan 10.000 rpm selama 3 menit. Debris sel mengendap dan DNA ada di supernatant.

\section{Amplifikasi dan Sekuensing}

Gen COI diamplifikasi menggunakan kit PCR dan primer universal gen COI : LCOI 1490-5'-GGTCAACAAATCATAAAGATATTGG3' dan HCOI 2198-5'TAAACTTCAGGGTGACCAAAAAATCA-3' (Gebhardt \& Knebelsberger, 2015). Siklus thermal yang digunakan adalah hasil 
optimasi yang dilakukan di laboratorium manajemen kesehatan hewan akuatik (MKHA) Balai Besar Perikanan Budidaya Air Payau Jepara. Amplifikasi dilakukan pada Hotstart 94 oC (5 menit), denaturasi $94 \circ \mathrm{\circ}$ (5 menit) diikuti 35 siklus 94 ${ }^{\circ} \mathrm{C}\left(1\right.$ menit), annealing $56{ }^{\circ} \mathrm{C} 1$ menit, ekstensi $72 \circ \mathrm{C}$ (1.5 menit) dan ekstensi akhir 72 ${ }^{\circ} \mathrm{C}\left(5\right.$ menit) serta Hold $12{ }^{\circ} \mathrm{C}$. Kegiatan amplifikasi ini dilakukan di laboratorium Hasil amplifikasi gen $\mathrm{COI}$ di sekuensing melalui Genetika Science Indonesia.

\section{Analisis data}

Sekuens gen $\mathrm{CO}$ dianalisis menggunakan perangkat lunak MEGA 5.20 meliputi edit/aligment menggunakan ClustalW. Sekuens diidentifikasi menggunakan BOLD system (http://www.boldsystems.org/index.ph p/IDS_OpenldEngine) dan BLAST (www.ncbi. $\mathrm{nlm}$.nih.gov/). Analisis filogenetika dilakukan dengan perangkat lunak MEGA 5.2 menggunakan metode statistik Neighborjoining (NJ) dan Maximum Likelihood (ML). Test phylogeny dengan bootstrap methods dan model Kimura 2-parameter. Jarak genetik, dihitung menggunakan fasilitas yang ada di MEGA 5.2. Data yang digunakan dalam rekonstruksi filogenetik meliputi spesimen rajungan $P$. trituberculatus yang diperoleh dari perairan Cirebon dan data FASTA gen $\mathrm{COI}$ spesimen rajungan $P$. trituberculatus yang diperoleh dari database $\mathrm{NCBI}$ (Tabel 1). Analisis haplotipe dan polimorfisme dilakukan menggunakan perangkat lunak DnaSP v.5.

Tabel 1. Data fasta sekuens gen COI spesimen rajungan P. pelagicus yang diambil dari database $\mathrm{NCBI}$ untuk rekonstruksi filogenetik (https://www.ncbi.nlm.nih.gov)

\begin{tabular}{lll}
\hline \multicolumn{1}{c}{ Spesimen } & \multicolumn{1}{c}{ Asal spesimen } & Acc. number \\
\hline P. trituberculatusvoucher CrP10 & Philippines: Pangasinan, Region 1 & KF604898.1 \\
P. trituberculatusvoucher CrP12 & $\begin{array}{l}\text { Philippines: Pangasinan, Region 1 } \\
\text { P. trituberculatusvoucher inb201306720 }\end{array}$ & KF604899.1 \\
China: Hubei, Wuhan, Huanan & KP976344.1 \\
supermarket & China: Hubei, Wuhan, Huanan \\
supermarket & KP976352.1 \\
P. trituberculatus voucher inb201306722 & $\begin{array}{l}\text { Chinabei, Wuhan, Huanan } \\
\text { supermarket }\end{array}$ & KP976349.1 \\
P. trituberculatus voucher inb201306727 & $\begin{array}{l}\text { China: Hubei, Wuhan, Huanan } \\
\text { supermarket }\end{array}$ & KP976354.1 \\
P. trituberculatus voucher inb201306728 & $\begin{array}{l}\text { China: Hubei, Wuhan, Huanan } \\
\text { supermarket }\end{array}$ & KP976355.1 \\
P. trituberculatus voucher inb201306729 & $\begin{array}{l}\text { China: Hubei, Wuhan, Huanan } \\
\text { supermarket }\end{array}$ & KP976356.1 \\
P. trituberculatus voucher inb201306733 & $\begin{array}{l}\text { China: Hubei, Wuhan, Huanan } \\
\text { supermarket }\end{array}$ & KP976343.1 \\
P. trituberculatus isolate De172910-1-1 & Korea & JX502944.1 \\
P. trituberculatus voucher CASMBGM-1PR & Tamil Nadu, India & MG753565.1 \\
P. trituberculatus voucher CASMBGM-PR33 & Tamil Nadu, India & MG753567.1 \\
P. trituberculatus isolate Potr2 & China & GQ180780.1 \\
P. trituberculatus isolate Potr3 & China & GQ180781.1 \\
P. trituberculatus isolate Potr4 & China & GQ180782.1 \\
P. trituberculatus isolate Potr5 & China & GQ180783.1 \\
P. trituberculatus haplotype 1 & China & GU321229.1 \\
P. trituberculatus haplotype 15 & China & GU321240.1 \\
P. trituberculatus haplotype 16 & China & GU321241.1 \\
P. trituberculatus haplotype 18 & China & GU321243.1 \\
\hline
\end{tabular}




\section{HASIL DAN PEMBAHASAN}

Hasil identifikasi spesimen rajungan CR 2 yang ditangkap di perairan Cirebon menggunakan barcoding bold system menunjukkan sebagai spesies $P$. trituberculatus dengan nilai kesamaan sebesar $99.67 \%$ demikian juga menggunakan analisis BLAST (The Basic Local Alignment Search Tool) NCBI menunjukkan kemiripan dengan P. trituberculatus sebesar 99\% (Tabel 2). Berdasarkan tingkat kesamaan dan identity yang sangat tinggi ( $\geq 99 \%$ ) menunjukkan bahwa DNA barcoding berdasarkan gen cytochrome c oxidase I (COI) mitokondrial dapat digunakan untuk identifikasi spesimen rajungan CR2. Hal ini sesuai dengan Hebert et al. (2003) bahwa DNA barcoding menggunakan fragmen pendek mitokondria efektif untuk diagnosis spesies. Informasi mengenai $P$ trituberculatus di Indonesia sangat sedikit sekali. Menurut FAO (2018) perairan Indonesia merupakan daerah distribusi jenis rajungan tersebut (Gambar 1).
Analisis filogenetik menggunakan data gen COI $P$. trituberculatus yang ada di database NCBI (21 dari China, 1 dari Korea, 2 dari India )dan 1 spesimen yang berasal dari tangkapan di perairan Cirebon menggunakan Neighbor-joining (NJ) methods (Saitou \& Nei 1987) dan Maximum Likelihood method (ML) menggunakan model Kimura 2parameter Kimura M. (1980)dengan bootstrap 1000 kali (Felsenstein 1985) dengan menunjukkan secara konsistensi pola garis keturunan yang sama (Gambar 2 dan Gambar 3). Penggunaan 2 spesies out group yaitu Octopus vulgaris laccession FN24381.1) dan Uroteuthis duvauceli (accession KC951889.1) pada pohon filogenetik menggambarkan semua garis percabangan $P$. trituberculatus berasal dari ancestor yang sama. Hal ini menunjukkan garis keturunan monofiletik (Baum et al., 2008). Berdasarkan hasil analisis filogenetik dengan 2 metode ini semua data set mengelompok kedalam 2 garis keturunan (lineage) yang berbeda yang berasal dari 1 ancestor yang sama. Pengelompokan ini

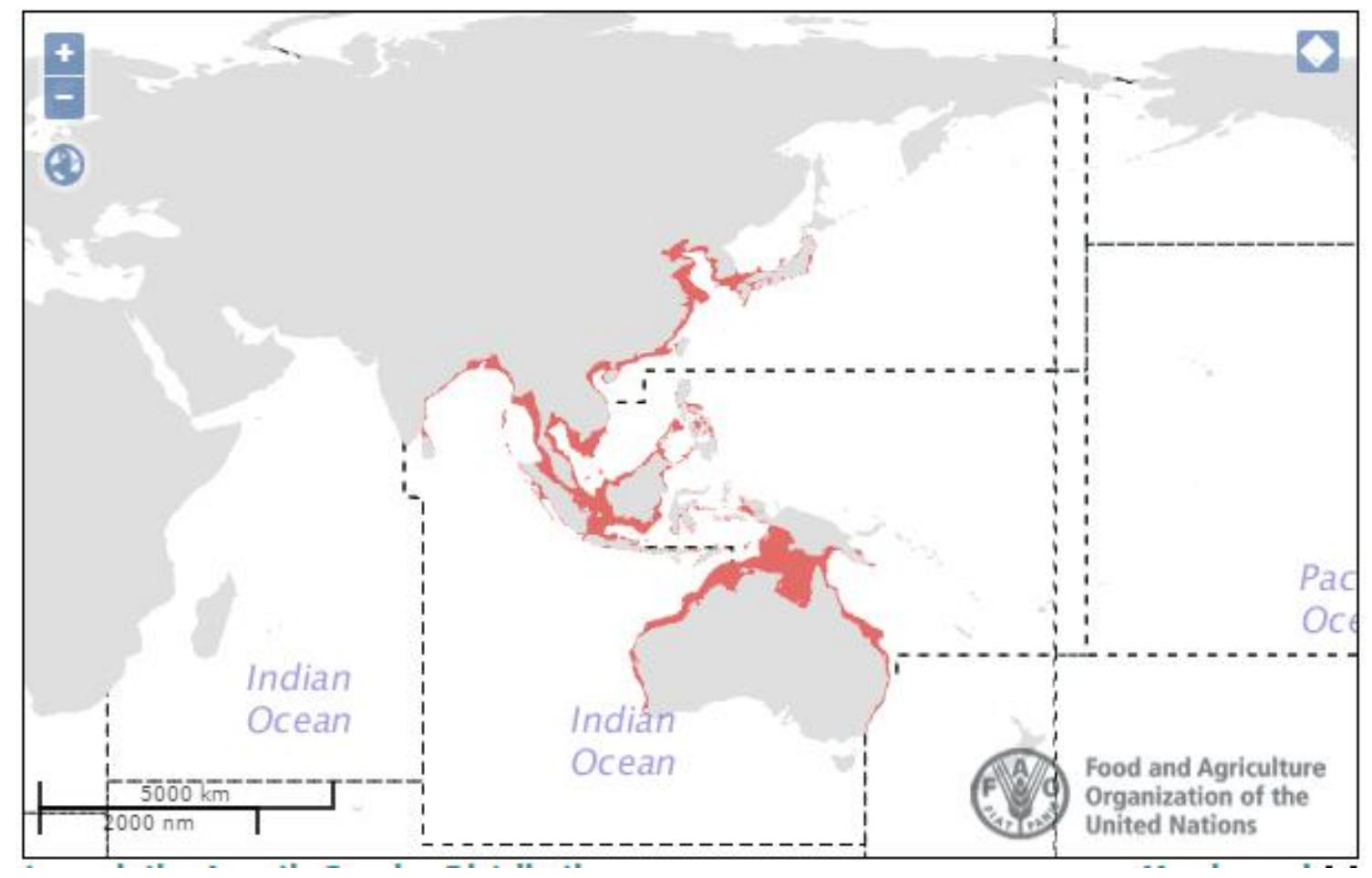

Gambar 1. Distribusi geografi $P$ trituberculatus

Keterangan $\square$ : pasti; $Y / /$ : tidak pasti ; $: \cdots . . . . .$. : $:$ area tangkapan FAO Sumber : FAO (2018) 
Tabel 2. Hasil identifikasi menggunakan BOLD system dan analisis blast NCBI

\begin{tabular}{cccccccc}
\hline Spesimen & Similaritas & Spesies & $\begin{array}{c}\text { Max } \\
\text { score }\end{array}$ & $\begin{array}{c}\text { Query } \\
\text { cover }\end{array}$ & Identity & Spesies & Accession \\
\hline CR2 & $99.67 \%$ & $\begin{array}{c}\text { Portunus } \\
\text { trituberculatus }\end{array}$ & 1094 & $100 \%$ & $99 \%$ & $\begin{array}{c}\text { Portunus } \\
\text { trituberculatus }\end{array}$ & KF604898 \\
\hline
\end{tabular}

Tabel 3. Jarak genetik tiga klaster $P$. trituberculatus. Diagonal kekanan merupakan nilai jarak genetic intra garis keturunan, nilai dibawah diagonal merupakan jarak genetic inter garis keturunan. Nilai diatas diagonal adalah standard deviasi jarak genetik inter garis keturunan

\begin{tabular}{cccc}
\hline & Lineage C & Lineage A & Lineage B \\
\hline & Klaster 3 & Klaster 1 & klaster 2 \\
\hline Lineage C, klaster 3 & 0,0292 & 0,0155 & 0,0149 \\
Lineage A, klaster 1 & 0,1424 & 0,0046 & 0,0158 \\
Lineage B, klaster 2 & 0,1276 & 0,1433 & 0 \\
\hline
\end{tabular}

Tabel 4. Distribusi haplotipe 25 spesimenP. trituberculatus. Jumlah urutan yang digunakan: 25 , Wilayah terpilih: 1-615 Jumlah situs: 615, Jumlah total situs (tidak termasuk situs dengan kesenjangan / data yang hilang): 610, Situs dengan kesenjangan penjajaran: tidak dipertimbangkan.

\begin{tabular}{|c|c|c|}
\hline Haplotipe & Spesimen & Asal spesimen \\
\hline Hap_1: 1 & KF604898.1 & Filipina \\
\hline Hap_2: 1 & KF604899.1 & Filipina \\
\hline Hap_3: 4 & KP976344.1 KP976349.1 KP976355.1 KP976343.1 & China \\
\hline Hap_4: 5 & KP976356.1 KP976354.1 KP976352.1 GU321243.1 GQ180779.1 & China \\
\hline Hap_5: 1 & $J \times 502944.1$ & Korea \\
\hline Hap_6: 2 & MG753567.1 MG753565.1 & India \\
\hline Hap_7: 1 & GQ180780.1 & China \\
\hline Hap_8: 1 & GQ180781.1 & China \\
\hline Hap_9: 1 & GQ180783.1 & China \\
\hline Hap_10: 1 & GU321241.1 & China \\
\hline Hap_11: 1 & GU321240.1 & China \\
\hline Hap_12: 1 & GU321229.1 & China \\
\hline Hap_13: 1 & CR2_Cirebon & Indonesia \\
\hline Hap_14: 1 & GU321230.1 & China \\
\hline Hap_15: 1 & GU321244.1 & China \\
\hline Hap_16: 1 & GU321242.1 & China \\
\hline Hap_17: 1 & GU321231.1 & China \\
\hline
\end{tabular}


didukung dengan nilai bootstrap sebesar 81 - 100 \%. Spesimen yang berasal dari China dan Korea berada dalam 1 garis keturunan yang sama (lineage A), spesimen India, Filipina dan Cirebon berada dalam 1 garis keturunan yang sama (lineage B). Selanjutnya garis keturunan B terbagi menjadi 2 klaster yaitu klaster yang terdiri dari specimen India dan klaster yang terdiri dari specimen Filipina dan specimen Cirebon. Pengelompokan ke dalam 3 kluster ini juga diperkuat oleh analisis jarak genetik antar kelompok (Tabel 3). Jarak genetik antara lineage A dan B sebesar $12,76 \%$, antara A dan B klaster 2 sebesar $14,24 \%$ dan antara B klaster 2 dan B klaster 3 sebesar 14,33\%. Sedangkan jarak genetik intralineage antara $0-2,92 \%$. Spesimen Cirebon karena berada di dalam klaster yang sama dengan spesimen Filipina menunjukkan adanya hubungan kekeraban yang dekat terutama dengan spesimen KF604898.1. Hal ini diukung

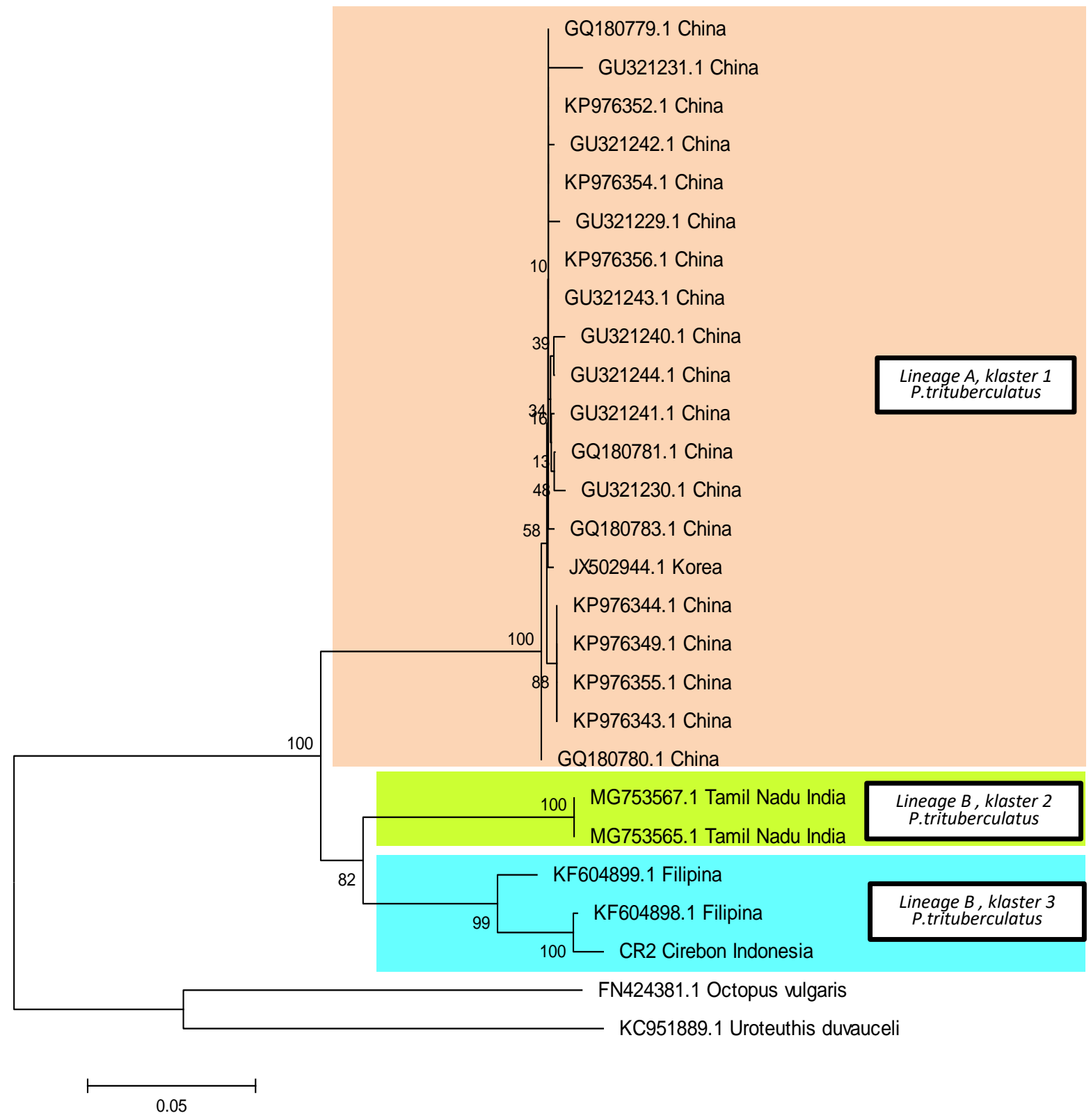

Gambar 2. Analisis hubungan filogenetika diantara $P$. trituberculatus berdasarkan gen COI sepanjang 602bp dengan metode Neighbor-Joining (model Kimura-2 parameter). Bootstrap (1000 replikan). Analisis menggunakan MEGA 5.2. 


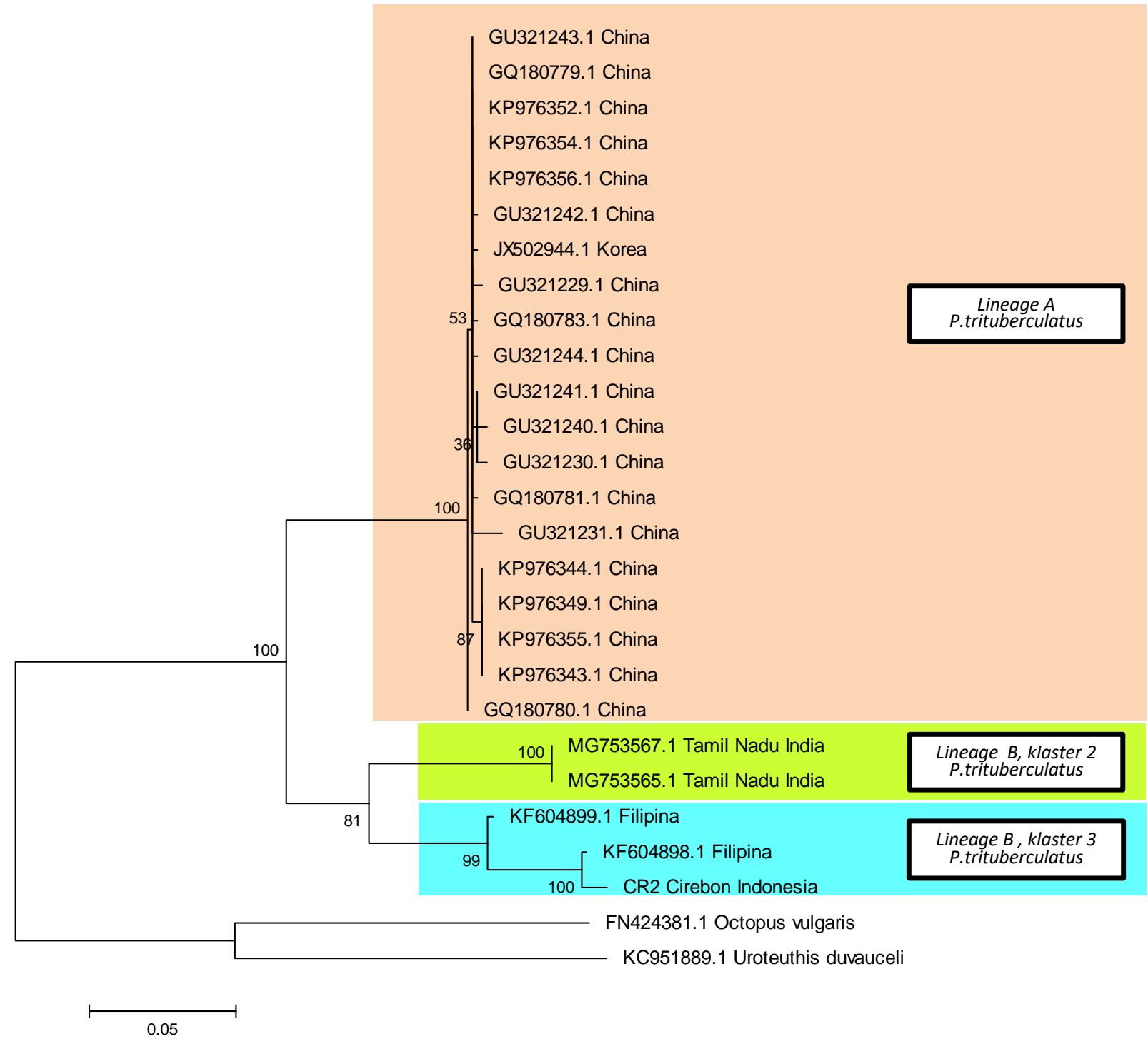

Gambar 3. Analisis hubungan filogenetika berdasarlan gen COI pada 25 sekuens $P$. trituberculatus dengan metode Maximum Likelihood dengan model Kimura 2-parameter. Bootstrap (1000 replikan). Analisis dilakukan di MEGA 5.2.

Tabel 5. Hasil analisis keragaman $P$. trituberculatus intra garis keturunan

\begin{tabular}{lccc}
\hline & Lineage A Kluster 1 & Lineage B Kluster 2 & Lineage B Kluster 3 \\
\hline Jumlah sekuens & 20 & 2 & 3 \\
Jumlah segregating sites, S & 20 & 0 & 26 \\
Jumlah haplotipes, h & 13 & 1 & 3 \\
Keragaman Haplotipe, Hd & 0,9158 & 0 & 1 \\
Keragaman Nukleotida, Pi & 0.0046 & 0 & 0.02842 \\
\hline
\end{tabular}

Tabel 6.Keragaman $P$. trituberculatus

\begin{tabular}{cccccc}
\hline Jumlah sekuen & $\begin{array}{c}\text { Jumlah } \\
\text { haplotipes }\end{array}$ & $\begin{array}{c}\text { Jumlah } \\
\text { tempat } \\
\text { polimorfik } \\
\text { segregating) }\end{array}$ & $\begin{array}{c}\text { Jumlah } \\
\text { total } \\
\text { mutasi }\end{array}$ & $\begin{array}{c}\text { Keragaman } \\
\text { Haplotipe }\end{array}$ & $\begin{array}{c}\text { Keragaman } \\
\text { Nukleotida }\end{array}$ \\
\hline 25 & 17 & 128 & 144 & $0,943 \pm 0.031$ & $0,04821 \pm 0.0139$ \\
\hline
\end{tabular}


dengan nilai bootstrap sebesar $100 \%$. Kedekatan ini juga ditunjukkan oleh jarak genetik antara spesimen Filipina KF604898.1 dengan spesimen Cirebon sebesar $1 \%$.

Hasil analisis haplotipe menggunakan DnaSP $\vee 5$ menunjukkan bahwa lienage A terdapat 20 sekuens yang terdistribusi dalam 13 haplotipe, pada lineage B kluster 2 terdapat 2 sekuens yang terdistribusi dalam 2 haplotipe dan pada lineage B kluster 3 terdapat 3 sekuens yang terdistribusi ke dalam 3 haplotipe (Tabel 4 ). Keragaman haplotipe tertinggi terdapat di lineage $B$ kluster 3 yaitu sebesar 1 dan terendah di lineage B kluster 2 sebesar 0 . Keragaman nucleotide tertinggi terjadi di lineage B kluster 3 yaitu sebesar 2,842 \% dan terendah di lineage B kluster 2 sebesar 0 (Tabel 5). Analisis keragaman terhadap 25 sekuens menunjukkan semua data tersebar kedalam 17 haplotipe dan spesimen rajungan Cirebon merupakan satu haplotipe tersendiri yang terpisah dengan data rajungan lainnya (Tabel 4). Hasil analisis keragaman seluruh data $P$. trituberculatus yang ada teridentifikasi sebanyak 128 situs polimorfik dan jumlah mutasi sebanyak 144, keragaman haploid sebesar $0,943 \pm 0.031$ dan keragaman nukleotida sebesar 0,04821 \pm 0.0139 (Tabel 6). Kelompok garis keturunan $A$ beranggotakan spesimen dari China dan Korea. Hasil penelitian Guo et al. (2009) terhadap P.trituberculatusdi sepanjang pantai China didapatkan 53 mtDNA haplotipes dari 72 individu dan 102 situs mutasi terdeteksi di 617 bp. Keragaman haplotipik dan keanekaragaman nukleotida berkisar antara 0,733-1,00 dan 0,00759-0,02614. Hasil yang lain didapatkan oleh Xu et al., (2009) melalui studi menggunakan metode Amplified Fragment Length Polymorphisms (AFLPs) terhadap 213 samples P.trituberculatusyang diperoleh di 3 area tangkap East China Sea, Yellow Sea, dan Bohai Sea terdistribusi ke dalam 25 haplotipe dengan 22 variable sites.

\section{KESIMPULAN}

DNA barcoding menggunakan gen Cytochrom oxidase sub unit I mitokondrial dapat digunakan untuk identifikasi spesies rajungan. Pada penelitian ini spesimen rajungan $P$. trituberculatus, dari perairan Cirebon dapat diidentifikasi secara akurat dengan tingkat similaritas sebesar 99,67\%. Hasil analisis filogenetik dengan 24 spesies yang sama yang berasal dari China, Korea, India dan Filipina (data diambil dari gen bank NCBI) menunjukkan bahwa spesimen Cirebon secara genetis masuk ke dalam kelompok garis keturunan yang sama dengan spesies Filipina. Sedangkan berdasarkan analisis distribusi haplotipe menunjukkan spesimen Cirebon merupakan haplotipe tersendiri.

\section{DAFTAR PUSTAKA}

Abbas E.M., Abdelsalam K.M., MohammedGeba K, Ahmed H.O, and Kato M., 2016, Genetic and morphological identification of some crabs from the Gulf of Suez, Northern Red Sea, Egypt, The Egyptian Journal of Aquatic Research, 42, 3:319-329

Apreshgi, K. P., K. V. Dhaneesh, Radhakrishnan T. and Kumar A.B, 2016, DNA barcoding of fiddler crabs Uca annulipes and U. perplexa (Arthropoda, Ocypodidae) from the Ssouthwest coast of India, J. Mar. Biol. Ass. India, 58 (1), doi: 10.6024/jmbai.2016.58.1.1865-13

Aranishi, F., T. Okimoto, 2006, A simple and reliable method for DNA extraction from bivalve mantle J Appl Genet 47(3):251254

Baum, D. (2008) Reading a phylogenetic tree: The meaning of monophyletic groups. Nature Education 1 (1):190

Fisheries and Aquaculture Department, 2018, Eshragh, R. \& B. S. Leander, 2014, Molecular contributions to species boundaries in dicyemid parasites from eastern Pacific cephalopods, Marine Biology Research., doi : 10.1080/ 17451000.2014 .943241

FAO, 2018, Species Fact Sheets Portunus trituberculatus (Miers, 1876), http://www.fao.org/fishery/species/263 o/en

Fujaya, Y., Asphama, A. I., Hidayani, A. A., Parenrengi, A. \& Tenriulo, A. (2016). High genetic vari ation of Portunus pelagicus from Makassar Straits revealed by RAPD 
markers and mitochondrial 165 rRNA sequences. African Journal of Biotechnology , 15(7), 180-190

Gebhardt, K. \& T. Knebelsberger, 2015, Identification of cephalopod species from the North and Baltic Seas using morphology, $\mathrm{COI}$ and 18S rDNA sequences, Helgol Mar Res, 69:259-271, DOI 10.1007/s10152-015-0434-7

Guo E, Liu Y, Cui Z, Li X, Cheng Y, Wu X., 2012, Genetic variation and population structure of swimming crab (Portunus trituberculatus) inferred from mitochondrial control region. Mol Biol Rep. 39(2):1453-63. doi: 10.1007/s11033011-0882-3. .

Habib, M., W. S. Lakra, V. Mohindra, P. Khare, A. S. Barman, A. Singh, K. K. Lal, P. Punia, A. A. Khan, 2011, Evaluation of cytochrome b mtDNA sequences in genetic diversity studies of Channa marulius (Channidae: Perciformes), Mol Biol Rep, 38:841-846 DOI 10.1007/s1 1033010-0175-2.

Hebert, P. D. N., Cywinska, A., Ball, S. L., \& deWaard, J. R., 2003, Biological identifications through DNA barcodes. Proceedings of the Royal Society B: Biological Sciences, 270(1512) : 313-321. http://doi.org/10.1098/rspb.2002.2218

Irawan, B dan Soegianto, A., 2006, Kekayaan Jenis Portunidae Di Sisi Shipping Line Selat Madura, Berk. Penel. Hayati, 11:93-96.

Klinbunga, S., Thamniemdeec, N., Yuvanatemiya, $\quad$., Khetpu,K., Khamnamtong , B., Menasveta, P., 2010, Species identification of the blue swimming crab Portunus pelagicus in Thai waters using mtDNA and RAPDderived SCAR markers, Aquaculture 308:S39-S46

Liu, S., Sun, J., Hurtado, L.A., 2013, Genetic differentiation of Portunus trituberculatus, the world's largestcrab fishery, among its three main fishing areas, Fisheries Research 148: 38- 46. http://dx.doi.org/10.1016/j.fishres.2013.0 8.003

Mantelatto, F.L., Robles, R. and Felder, D.L., 2007, Molecular phylogeny of the western Atlantic species of the genus
Portunus (Crustacea, Brachyura, Portunidae), Zoological Journal of the Linnean Society, 150: 211-220

Naz, F., Saher, N.U., And Kama, M., 2016, Genetic Diversity of The Portunus Sanguinolentus (Herbst, 1783) (Decapoda, Brachyura, Portunidae) In Indo West Pacific Region Based On Mitochondrial Dna 16s Gene, Pakistan Journal of Marine Sciences, 25 (1\&2), 59-68,

Raupach, M.J., Radulovici A.E., 2015, Looking back on a decade of barcoding crustaceans. ZooKeys 539: 53-81. doi: 10.3897/zookeys.539.6530

Ren G., Ma H., Ma C., Wang W., Chen W., \& Ma L, 2017, Genetic diversity and population structure of Portunus sanguinolentus (Herbst, 1783) revealed by mtDNA COI sequences, Journal Mitochondrial DNA Part A DNA Mapping, Sequencing, and Analysis , 28 (5) : 740-746

Ren G, Ma H, Ma C, Wang W, Chen W, Ma L., 2017, Genetic diversity and population structure of Portunus sanguinolentus (Herbst, 1783) revealed by mtDNA COI sequences. Mitochondrial DNA A DNA Mapp Seq Anal. 28(5):740-746. doi: 10.1080/24701394.2016.1177040.

Shen Y-Y, Chen X, Murphy R.W. , 2013, Assessing Dna Barcoding As A Tool For Species Identification And Data Quality Control. Plos One 8(2): E57125. Doi:10.1371/Journal.Pone.0057125

Sienes, P.M.Q, Willette, D.A., Romena, L.R., Alvior, C. G. and Estacion J.S. 2014, Genetic diversity and the discovery of a putative cryptic species within a valued crab fishery, Portunus pelagicus (Linnaeus 1758), in the Philippines, Philippine Science Letters, 7 (2):317-323.

Umamaheswari, S., P. S. Bhavan, R. Udayasuriyan, C. Vadivalagan and $R$. Kalpana, 2016, Discrimination of four marine crabs and one freshwater crab through mt-COI gene, Journal of Entomology and Zoology Studies, 4(5): 766-782

Xu , Q., Liu, R., Liu Y., 2009, Genetic population structure of the swimming crab, Portunus trituberculatus in the East 
China Sea based on mtDNA 16S rRNA sequences, Journal of Experimental
Marine Biology and Ecology 371:121129. doi:10.1016/j.jembe.2009.01.014 